
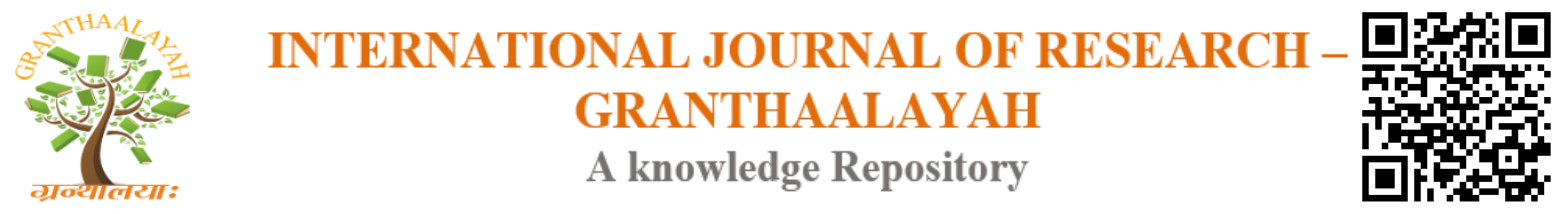

Management

\title{
AN ECONOMIC ANALYSIS OF SOLID WASTE MANAGEMENT OF IBADAN METROPOLIS, OYO STATE: EVIDENCES FROM VALUE BELIEF NORM (VBN) AND WILLINGNESS-TO-PAY THEORY
}

\author{
Aduralere Opeyemi Oyelade *1 \\ ${ }^{* 1}$ University of Ibadan, Nigeria
}

\begin{abstract}
The study investigated the economic analysis of solid waste management of Ibadan metropolis, Oyo State: Evidences from value belief norm (VBN) and willingness-to-pay theory. The study distributed two hundred and fifty (250) to both household and contractors and two hundred questionnaires was distributed to household while fifty questionnaires for contractors. The methods used include descriptive statistic, cross tabulation, both ordinary least square (OLS) and logistic regression as well as gross margin and net income analysis. The OLS regression result revealed that income of the household, educational status, age and sex are the factors that determine the amount pay to Ibadan waste management per month in Ibadan metropolis while the factors that determine willingness-to-pay for environmental goods in Ibadan metropolis from logistic regression are income of the household, household size, educational status, occupation and sex and they are inelastic in nature. Furthermore, gross margin and net income from waste management business to the contractors sampled are N100,408.5299 and N86,852.20 per month respective. The study recommended that contractors in the study area can jointly establish recycle plants where they can recycle waste and make more income from the recycled products. Waste management contractors should be prompt in their service delivery. Also, every household should have solid waste facilities such as garbage bin and dustbin for easy disposal. Lastly, government should re-introduced the monthly sanitation in order to make a lot of household become more conscious of the purity of their surroundings.
\end{abstract}

Keywords: Economic Analysis; Solid Waste Management; Value Belief and Willingness-to-Pay Theory.

JEL Classification: Q50, Q51, Q52, Q53, Q58

Cite This Article: Aduralere Opeyemi Oyelade. (2019). "AN ECONOMIC ANALYSIS OF SOLID WASTE MANAGEMENT OF IBADAN METROPOLIS, OYO STATE: EVIDENCES FROM VALUE BELIEF NORM (VBN) AND WILLINGNESS-TO-PAY THEORY." International Journal of Research - Granthaalayah, 7(4), 106-125. https://doi.org/10.29121/granthaalayah.v7.i4.2019.880. 


\section{Introduction}

Solid waste management study is highly essential on the ground that the World has moved away from the popular millennium development goals which ended in 2015 and the World is focusing on sustainable development goals which are relatively new concepts and catching the attention of World environmental agencies in their bid for the World to a better place for the humanity. Economic analysis of solid waste disposal methods are based on cost of disposing solid wastes and composition of solid waste. The economic analysis of solid waste management is based on four element which are economic, technical, social and environment. Economic has to do with capital and operational cost; potential and maintenance cost; reducing cost associated with conventional waste process and disposal and labour cost. Technical include potential and maintenance cost; degree of adaptation at all levels and compatibility with existing system and technology which social element are potential resettlement of people; potential for local job creation and relation with producers. Environment has to do with noise and visual pollution, transportation and greenhouse gas emission (Ugwu and Ahaneku, 2015). Rapid population growth, urbanization and industrial growth have led to severe problems of waste management in Nigeria cities. The typical structure, scale and scope of city economic development are creating uninvited impacts on the safety of the natural environment. Waste disposal in Nigeria is dominated by indiscriminate dumping of refuse, inefficient collection and sorting, poor documentation of waste composition and generation rate by household and industries, and incompetent management by informal sector. It has been estimated that a range of $521.95-759.20 \mathrm{~kg}$ of waste is generated per person per year in the developed countries while waste generated per person per year in developing countries is put at $109.50-525.60 \mathrm{~kg}$ (Ugwu and Ahaneku, 2015).

Therefore, this study is set to investigate the economic analysis of solid waste management of Ibadan metropolis, Oyo State: Evidences from value belief norm (VBN) and willingness-to-pay theory. In addition, most studies conducted on solid waste management has been focusing on more of the environmental impact of solid waste management with relatively few studies on the economic impact of solid waste management. This study will therefore buffer the few studies on the economic impact of solid waste management on both the individual households as well as government. The research work is organized into five sections. Section one covers the introduction and section two covers the literature review. Section three focuses on theoretical framework and methodology while section four deals with results and discussion. Finally, section five deals with summary and conclusion.

\section{Literature Review}

Although various studies have been carried out on solid waste management in different dimensions. Most of these studies use different scope, methods, theories, variables and apparently came up with different results. However, some came up with the same results while others came up with something contrary. Ajani, (2008) analyzed the factors that determine the employment of waste service providers as well as the amount paid for the services by the recipients in Ibadan metropolis. The results revealed that age of recipients, location of recipients and occupation of recipients were positively related to the probability of using public waste collection service while the number of years of schooling, amount paid for waste collection service, household size and total monthly income of recipient were negatively related to the probability of using public waste collection service. Years of schooling and the amount paid for waste collection service were 
statistically significant. The results also revealed that among the socio-economic variables which affect the amount spent on waste collection service, total monthly income and employment of public waste collection service were statistically significant.

Ibiyemi, (2008) investigated the economics of solid waste management in Lagos State. The result showed that of the solid wastes generated in Lagos State, less than $20 \%$ was recovered. There is also no market for components separation. Awosusi, (2010) assessed the environmental problems and methods of waste management in Ado-Ekiti, Nigeria. Results from the study showed that waste management personnel have contributed immensely to the management of waste in the area. However, they are confronted with some problems, which, if given the necessary encouragements, will be great help in the management of waste system in the area.

Anthony, (2011) examined impact of municipal solid wastes on underground water sources in Nigeria. The study findings revealed that samples from Solous dumpsite did not confirm pollution from leachates thereby suggesting that the water from the nearby wells is portable and can be used consumed. On the other hand, analysis of water samples from Olusosun dumpsite and surrounding areas confirmed the presence of feacal coliforms during microbiological analyses, suggesting that the water sample collected from Olusosun is not suitable for consumption. Adebo and Ajewole, (2012) examined the factors that might influence willingness-to-pay for waste disposal among male and female gender in Ekiti State, Nigeria. The results showed that willingness-to-pay for waste disposal was significantly affected by gender; nature of primary occupation; marital status; level of education and average monthly income. However, family size, household headship and nearness to dump site all have a negative relationship with willingness to pay for waste disposal in Ekiti State.

Adeoti and Obidi, (2013) assessed household's preference for improved solid waste management in Asaba, Delta-State. The likelihood of households choosing an improved waste management option was influenced positively by the educational status of the household head, the number of working household members and negatively by the household's poverty status. The mean willingness to pay estimate is $\$ 1546.32$ per month but reduced to $\$ 619.80$, with consideration given to their socioeconomic characteristics. Abur et al, (2014) presented the characteristic of the municipal solid waste generated in the Federal Capital Territory, Abuja, Nigeria. The characteristics of the municipal solid waste were determined in terms of the components, average mass $(\mathrm{kg})$ and percentage generated per district. It was found that $56.20 \% / 52.0 \%$ of the solid waste generated in the area is made up of food/ petrucsible; rubber $10.20 \% / 3.56 \%$; paper $10.00 \%$ / $12.46 \%$; glass/ceramics $7.60 \% / 1.42 \%$; plastics $7.4 \% / 2.85 \%$; metals $2.60 \% / 0.71 \%$ and other forms of waste $5.60 \% / 25.62 \%$ (dust particle, Ash, stones) for wet and dry seasons respectively and the waste generation rates ranged from 0.59 to $0.79 \mathrm{~kg} / \mathrm{capita} /$ day.

Lohri et al, (2014) presented a cost-revenue analysis, based on data from July 2009 to June 2011. The results of the research therefore showed that a more detailed cost structure and cost-revenue analysis of this waste management service is important with appropriate measures, either by the privates sector itself or with the support of the local authorities, in order to enhance cost efficiency and balance the cost-revenues towards cost recovery. Agbaeze et al, (2014) sought to find out the current state of solid waste management system in the state, and to identity factors that influences waste management and the type of solid waste management system that will aid economic 
development of the State. It was observed that the solid waste management system in practice in the state is unscientific, unsustainable and at the prerogative of people in power. It was discovered that the current waste management system has no room for waste recycling, reuse and repair. The study also analyzed the newly proposed solid waste management system in the state and found that the proposed system will be better than the existing one if efficiently implemented.

Aliu et al, (2014) examined the performance of public private partnership in household solid waste collection in Lagos, Nigeria. Regression models indicated that the public private partnership performance is significantly influenced by economic status, affordability, flexibility, consistency, cleanliness, coverage and accessibility, as well as number of waste collection vehicles, vehicle maintenance, capacity, trip rate, frequency, number of personnel and quality of personnel. Findings from this study reveal that Lagos residents have strong positive perception of public private partnership as a waste collection policy framework. Tan et al, (2015) evaluated the energy, economic and environmental (3E) impact of waste-to-energy (WTE) for municipal solid waste management. The study presented an interactive comparison of different WTE scenarios and followed by further discussion on waste incineration and AD as the two potential WTE options in Malaysia. The 3E assessment reveals incineration as the superior technology choice when the production of electricity and heat were considered; however, AD is found to be more favourable under the consideration of electricity production only.

Gillani et al, (2015) evaluates the economic burden of diseases associated to the inappropriate disposal of solid waste at dumpsite located at the Hazar Khwani, Peshawar provincial headquarters of Khyber Pakhtunkhwa Province of Pakistan. Results suggested an inverse and significant association between the distances and work days lost and mitigation costs, respectively. Annualized monetary benefit of adoption of scientific and modern techniques of landfill management to the locals ranges from 186,612,897.66 PKR to192,559,787.244 PKR especially for residents living within the proximity of $4 \mathrm{~km}$ of the dumpsite. Ugwu and Ahaneku, (2015) analysed the solid waste disposal in Nigeria with the aim of findinga method with minimum cost of disposing such waste. The results of the analysis show that MBT is a favourable option for the disposal of solid waste in Nigeria. This is because waste generated in Nigeria are predominantly biodegradable in composition.

Yusuf and Adesola, (2015) examined the benefit incidence accruing to households from government expenditure on solid waste management in Olorunda Local Government Area of Osun State, Nigeria. The result showed that average household spending on solid waste disposal service by the user of government facilities was $\$ 252.98$, which was more than the government unit subsidy on solid waste management of $\$ 14.00$. About $63 \%$ of the total government expenditure on solid waste management accrues to the poor but more disproportionately in favour of the moderately poor. Ayanshola et al, (2015) evaluated the households' usage of the current solid waste management system (SWMS) within the city of Ilorin, central Nigeria. The study found that $36 \%$ and $64 \%$ respectively of the households were unsatisfied and moderately satisfied with the current waste management system. The combined effect of household's demographic profiles, geometric profile and position of waste management facility gave a significant fitted model to show the relationship between household's willingness to pay and the considered predictors. 
Miyata et al. (2016) examined the economic analysis of municipal solid waste management of Toyohashi city, Japan: Evidences from environmental Kuznets curve. The inverse U-shaped EKC for Toyohashi city proves that the relation between per capita economic level, per capita city expenditures for municipal waste management and per capita municipal solid waste can be explained by changes in national and local level initiatives accompanied by economic development and quality of life. Interpretation of such outcome was that in Japan national level policy and legal agenda reflects in local governmental level as Toyohashi city was able to improve its citizen's quality of life by addressing environmental pollutions problems by the support of higher income and better technology. The EKC of the city demonstrate that idea of sound-material based society could play a vital role in the management of the waste. Igwe and Mgbasonwu, (2017) assessed the economic analysis of household waste generation, disposal and management in Umuahia metropolis, Abia State, Nigeria. The finding revealed that income, educational level were positively significant at $1 \%$. While household size was negatively significant at $1 \%$ level. It was found out the unit pricing on municipal waste charges is the best alternative to the current flat rate that are in practice in the state.

Eleje et al, (2017) assessed financial and economic relevance of solid waste management in Nigeria. Two major hypotheses were formulated to govern the study. Descriptively, a large proportion of respondents strongly agreed that solid waste management has significant effect on internally generated revenue (IGR) and youth employment in the state. Consistently, the computed $\mathrm{Z}$ values laid between -1.96 and 1.96 of their critical values implying the acceptance of the two alternative hypotheses.

\section{Theoretical Framework and Methodology}

\subsection{Theoretical Framework}

The research work make used of value belief norm (VBN) theory propounded by Stern, (2000) and willingness-to-pay theory as the theoretical framework. VBN focuses on values and moral norms. The theory holds that pro-environmental actions occur in response to personal moral norms about such actions and that these are activated in individuals who believe that environmental conditions pose threats to other people, other species, or the biosphere (awareness of consequences or AC) and that actions they initiate could avert those consequences (ascription of responsibility to self, or AR). For those behaviours not strongly constrained by contextual forces, individual choice about pro-environmental actions can be driven by personal norms - an internalized sense of obligation to act in a certain way. Norms are activated when an individual believes that violating them would have adverse effects on things they value and that by taking action, they would bear significant responsibility for those consequences. Personal values (e.g., altruistic values, egoistic values) are antecedents of environmental beliefs.

Also, willingness-to-pay theory state that economic valuation is about "measuring the preferences" of people for an environmental good or against an environmental bad. The economic value of something is measured by a summation of many individuals ' willingness to pay (WTP) for it. The WTP reflects individuals' preferences for the good in question. Valuation is in money terms because of the way in which preference revelation is sought. i.e., by asking people how much they are willing to pay environment waste. 


\subsection{Model Specification, Data Source and Estimation Techniques}

The research work adopted a model from the work of Igwe and Mgbasonwu, (2017) who also uses value-belief-norm (VBN) theory to build household budget constraint to describe the options of waste disposal available for the household with limited income (or wealth) to allocate among various waste categories generated at household level.

$$
\mathrm{Y}=\mathrm{P}_{1} \mathrm{X}_{1}+\mathrm{P}_{2} \mathrm{X}_{2}
$$

The budget constraint is a given element of the problem household faced. From the concept of consumer's behavior, household utility is the satisfaction derived from consuming any commodity. By consumption of any commodity, waste is generated, and certain cost is attached to the disposal of this waste by the regulatory agency. These costs depend on the household income. Thus the household is faced with budget constraint. Suppose after consumption of commodities $\left(\boldsymbol{X}_{1}\right)$ and waste $\left(x_{2}\right)$ is generated. The purchase of these commodities and disposed of waste generated are made possible with a given amount of money $\left(\mathrm{P}_{1}\right.$ and $\left.\mathrm{P}_{2}\right)$ which depends on the household income (Y) in naira per month. Thus the budget constraint is writing as in equation (1) above to shows that the total amount of money $\mathrm{P}_{1}$ and $\mathrm{P}_{2}$, used for consumption $\left(x_{1}\right)$ and disposal $\left(x_{2}\right)$ must not exceed the income $\mathrm{Y}$ available to household. For the purpose of this study, the study assume that $\mathrm{Y}$ is completely exhausted. A prior expectation is that when regulator charge is higher than household available income it results to illegal waste disposal and vice versa. The model considers analyzing factors like income, household size, education etc which describe the processes of waste generation. The major determinants are assumed to be family monthly income (Y), household size (HS), educational level (EDU), and housing type (H), extra land area (L). The model for the waste component will be:

$$
\mathrm{AP}=\beta_{0}+\beta_{1} \mathrm{Y}+\beta_{2} \mathrm{HS}+\beta_{3} \mathrm{EDU}+\beta_{4} \mathrm{H}+\beta_{5} \mathrm{~L}+\beta_{6} \mathrm{~W}+\beta_{7} \mathrm{~A}+\beta_{8} \mathrm{~S}+\varepsilon \ldots \ldots \ldots \ldots . .(2)
$$

Where AP = Amount Pay to Ibadan Waste Management per Month; Y = Income of the Household (N/Month); HS = Household Size (Numbers of Persons); EDU = Educational Status, (in Years); $\mathrm{H}=$ Housing Type (whether residential or not); L = Extra Land Area (in Plot); W = Quantity of Waste per Household per day $(\mathrm{Kg} /$ day); $\mathrm{A}=$ Age (in years), $\mathrm{S}=\mathrm{Sex}$ (Male or Female) and $\varepsilon=$ Error Term while $\beta_{1}, \beta_{2}, \beta_{3}, \beta_{4}, \beta_{5}, \beta_{6}, \beta_{7}$ and $\beta_{8}$ are the parameters to be estimated. Here household is assumed as a production unit producing wastes.

Also, the model for willingness-to-pay for environmental goods was adopted from the work of Maloma and Sekatane, (2014) that made used of willingness-to-pay theory for reduction of environmental waste. In their work, they believed that binary choice models such as logistic and probit models are commonly used in environmental valuation studies to predict dichotomous outcomes that is if a person is either willing to pay or not. The response variable can take only two values namely 1 if the person is willing to pay and 0 if not. The logistic regression model of the above relationship is given below: 
$\operatorname{Pr}\left(W T P=\frac{1}{X_{n}}\right)=\frac{1}{1+e^{-\left(\beta_{0}+\beta_{1} \mathrm{Y}+\beta_{2} \mathrm{HS}+\beta_{3} \mathrm{EDU}+\beta_{4} \mathrm{O}+\beta_{5} \mathrm{M}+\beta_{6} \mathrm{~A}+\beta_{7} \mathrm{~S}\right)}}$

Where WTP = Willingness-to-pay for environmental waste ( 1 if the household is willing to pay and $=0$ if otherwise); $\mathrm{Y}=$ Income of the Household (N/Month); HS = Household Size (Numbers of Persons); EDU = Educational Status, (in Years); $\mathrm{O}=$ Occupation; $\mathrm{M}=$ Marital Status; A = Age (in years) and $\mathrm{S}=\mathrm{Sex}($ Male $=1$ or Female $=0)$

Since the study is on economic analysis of solid waste management in Ibadan metropolis, Oyo State, the economic analysis of solid waste was also carried out based on reused, recycling and reduction and by so done, the profit analysis on the revenue and cost incurred by the contractors in the study area using gross margin and net income was done. Gross margin (GM) analysis was used to examine the profitability of solid waste management business in the study area.

$\mathrm{GM}=$ Total Revenue - Total Variable Cost.

Net Income $(\mathrm{NI})=\mathrm{GM}-$ Total Fixed Cost $(\mathrm{TFC})$

Variable costs are the variable inputs like labour, fuel and rent on vehicle hired for the disposal. Common fixed inputs among the contractors are shovel and hand gloves. Most of the waste contractors may not own personal truck/vehicle for the business hence only rent and fuel costs were incurred. A straight line depreciation technique was used in the analysis. There monthly equivalent value was computed for the analysis. The study was based on primary data with the use of questionnaires and the study distributed two hundred and fifty (250) questionnaires but two hundred (200) questionnaires was distributed to the household while the remaining fifty (50) questionnaires was distributed to the contractors in Ibadan metropolis. Also, the study make use of ordinary least squares method (OLS) and Logistic (logit) regression approach.

\section{Results and Discussion}

Table 1: Socio-Economic Characteristics of both Household and Contractors

\begin{tabular}{|l|l|l|l|}
\hline Questions & Category & Households & Contractors \\
\cline { 3 - 4 } & & Percent (\%) & Percent (\%) \\
\hline \multirow{3}{*}{ Sex } & Male & 60.1 & 62.8 \\
\cline { 2 - 4 } & Female & 39.9 & 37.2 \\
\hline Age & Average Age & 37 & 32 \\
\hline \multirow{5}{*}{ Aarital Status } & Single & 33 & 27.9 \\
\cline { 2 - 4 } & Married & 62.2 & 72.1 \\
\cline { 2 - 4 } & Divorced & 4.8 & 0 \\
\hline \multirow{5}{*}{ Academic Level } & No formal education & 1.6 & 0 \\
\cline { 2 - 4 } & Primary education & 1.6 & 0 \\
\cline { 2 - 4 } & Secondary education & 11.2 & 72.1 \\
\cline { 2 - 4 } & Tertiary education & 63.3 & 27.9 \\
\cline { 2 - 4 } & Professional education & 22.3 & 0 \\
\hline Average monthly income & Average Income & $\mathbb{N} 45,894$ & $\mathbb{1} 18,186$ \\
\hline
\end{tabular}




\begin{tabular}{|l|l|l|l|}
\hline \multirow{4}{*}{ Religion } & Christian & 64.9 & 41.9 \\
\cline { 2 - 4 } & Muslim & 34.0 & 58.1 \\
\cline { 2 - 4 } & Traditional & 1.1 & 0 \\
\hline \multirow{5}{*}{ Household Size } & $1-4$ & 53.2 & 41.9 \\
\cline { 2 - 4 } & $5-8$ & 38.8 & 58.1 \\
\cline { 2 - 4 } & $9-14$ & 8.0 & 0 \\
\hline \multirow{5}{*}{ Household Type } & Residential & 36.7 & 27.9 \\
\cline { 2 - 4 } & Tenement type & 20.2 & 72.1 \\
\cline { 2 - 4 } & Bungalows & 15.4 & 0 \\
\cline { 2 - 4 } & Multistory Flat & 12.8 & 0 \\
\cline { 2 - 4 } & Single Story Flat & 14.9 & 0 \\
\hline
\end{tabular}

Source: Field Survey, 2018

Considering the respondents who are households from the Table 1 above, it was seen that $60.1 \%$ of the respondents were male while the remaining $39.9 \%$ are female. Also, in term of the age of the respondents, it was seen that the average age of the household in the research work was 37 years of age. Moreover, in term of marital status, $33 \%$ were single, $62.2 \%$ were married while the remaining $4.8 \%$ were divorced. Furthermore, talking about the academic level of the respondents, $1.6 \%$ have no formal education, $1.6 \%$ have primary education, $11.2 \%$ have secondary education, $63.3 \%$ have tertiary education while the remaining $22.3 \%$ have a professional education. In addition, the average monthly income of the household was $\$ 45,894$. Also, in considering the religion of the respondents, $64.9 \%$ were Christians, $34.0 \%$ were Muslim while the remaining $1.1 \%$ were traditionalists. Moreover, in term of the household size of the respondents, $53.2 \%$ of the respondents have $1-4$ number of households, $38.8 \%$ have $5-8$ number of households while the remaining $8 \%$ have $9-14$ number of households. Finally, in term of household type, $36.7 \%$ of the respondents live in a residential type of household, $20.2 \%$ live in a tenement type of household, $15.4 \%$ live in bungalows, $12.8 \%$ live in multistory flat while the remaining $14.9 \%$ of the respondents live in as single story flat. In total, respondents who live in a residential type of household have the highest percentage in this research work.

Considering the respondents who are contractors, it was seen that $62.8 \%$ of the respondents were male while the remaining $37.2 \%$ were female. In addition, in term of the age of the respondents, it was seen that the average age of the contractors in the research work was 32 years of age. Furthermore, in term of marital status, $27.9 \%$ were single while the remaining $72.1 \%$ were married. Moreover, talking about the academic level of the respondents, $72.1 \%$ have secondary education while the remaining $27.9 \%$ have tertiary education. Also, the average monthly income of the respondents was $\$ 18,186$. Furthermore, $41.9 \%$ were Christians while the remaining $58.1 \%$ were Muslims. Moreover, $41.9 \%$ of the respondents have $1-4$ numbers of households while the remaining $58.1 \%$ have $5-8$ number of households. In conclusion, $27.9 \%$ of the respondents live in a residential type of household while the remaining $72.1 \%$ live in a tenement type of household. 
Table 2: Crosstabs for the Economic Analysis of Solid Waste and Households Sex

\begin{tabular}{|c|c|c|c|c|c|}
\hline \multirow{2}{*}{ Questions } & \multirow{2}{*}{ Category } & \multicolumn{2}{|c|}{ Sex } & \multirow{2}{*}{ Total } & \multirow[b]{2}{*}{$\begin{array}{c}\text { Chi-Square } \\
\left(\chi^{2}\right) \text { and } \\
\text { Probability } \\
\text { Values }\end{array}$} \\
\hline & & Male & Female & & \\
\hline \multirow{13}{*}{$\begin{array}{l}\text { What types of waste } \\
\text { categories do you } \\
\text { dispose? }\end{array}$} & Food waste & $93(49.5 \%)$ & $\begin{array}{l}65 \\
(34.6 \%)\end{array}$ & $158(84.0 \%)$ & \\
\hline & Newspapers & $24(12.8 \%)$ & $\begin{array}{l}30 \\
(16.0 \%)\end{array}$ & $54(28.9 \%)$ & \\
\hline & Magazine & $28(15.0 \%)$ & $\begin{array}{l}19 \\
(10.2 \%)\end{array}$ & $47(25.1 \%)$ & \\
\hline & Carton boxes & $42(22.5 \%)$ & $\begin{array}{l}25 \\
(13.4 \%)\end{array}$ & $67(35.8 \%)$ & \\
\hline & $\begin{array}{l}\text { Refuse plastic } \\
\text { sacks }\end{array}$ & $87(46.5 \%)$ & $\begin{array}{l}55 \\
(29.4 \%)\end{array}$ & $142(75.9 \%)$ & \\
\hline & Plastic bottles & $77(41.2 \%)$ & $\begin{array}{l}57 \\
(30.5 \%)\end{array}$ & $134(71.7 \%)$ & \\
\hline & Metal & $42(22.5 \%)$ & $\begin{array}{l}35 \\
(18.7 \%)\end{array}$ & $77(41.2 \%)$ & \\
\hline & Glass & $21(11.2 \%)$ & $\begin{array}{l}23 \\
(12.3 \%)\end{array}$ & $44(23.5 \%)$ & \\
\hline & $\begin{array}{l}\text { Used clothes and } \\
\text { fabrics }\end{array}$ & $59(31.6 \%)$ & $\begin{array}{l}31 \\
(16.6 \%)\end{array}$ & $90(48.1 \%)$ & \\
\hline & Vegetable matter & $63(33.7 \%)$ & $\begin{array}{l}55 \\
(29.4 \%)\end{array}$ & $118(63.1 \%)$ & \\
\hline & Grits & $54(28.9 \%)$ & $\begin{array}{l}46 \\
(24.6 \%)\end{array}$ & $100(53.5 \%)$ & \\
\hline & Hedges and trees & $40(21.4 \%)$ & $\begin{array}{l}47 \\
(25.1 \%)\end{array}$ & $87(46.5 \%)$ & \\
\hline & Rubber & $61(32.6 \%)$ & $\begin{array}{l}55 \\
(29.4 \%)\end{array}$ & $116(62.0 \%)$ & \\
\hline \multirow{4}{*}{$\begin{array}{l}\text { How many plot of } \\
\text { land was your } \\
\text { accommodation } \\
\text { build on? }\end{array}$} & A plot of land & $57(30.3 \%)$ & $\begin{array}{l}51 \\
(27.1 \%)\end{array}$ & $108(57.4 \%)$ & \multirow[t]{4}{*}{$8.264(0.041)$} \\
\hline & $\begin{array}{l}\text { Two plots of } \\
\text { land }\end{array}$ & $29(15.4 \%)$ & $\begin{array}{l}13 \\
(6.9 \%)\end{array}$ & $42(22.3 \%)$ & \\
\hline & $\begin{array}{l}\text { Three plots of } \\
\text { land }\end{array}$ & $10(5.3 \%)$ & $\begin{array}{l}1 \\
(0.5 \%)\end{array}$ & $11(5.9 \%)$ & \\
\hline & Others & $17(9.0 \%)$ & $\begin{array}{l}10 \\
(5.3 \%)\end{array}$ & $27(14.4 \%)$ & \\
\hline \multirow[t]{3}{*}{$\begin{array}{l}\text { Duration of waste } \\
\text { generation (Days) }\end{array}$} & $1-2 \mathrm{Kg} / \mathrm{day}$ & $81(43.1 \%)$ & $\begin{array}{l}44 \\
(23.4 \%)\end{array}$ & $125(66.5 \%)$ & \multirow[t]{3}{*}{$5.680(0.128)$} \\
\hline & $3-4 \mathrm{Kg} / \mathrm{day}$ & $27(14.4 \%)$ & $\begin{array}{l}24 \\
(12.8 \%)\end{array}$ & $51(27.1 \%)$ & \\
\hline & $5-6 \mathrm{Kg} / \mathrm{day}$ & $5(2.7 \%)$ & $\begin{array}{l}5 \\
(2.7 \%)\end{array}$ & $10(5.3 \%)$ & \\
\hline
\end{tabular}


DOI: 10.5281/zenodo.2653134

\begin{tabular}{|c|c|c|c|c|c|}
\hline & $\begin{array}{l}7 \mathrm{Kg} / \text { day and } \\
\text { above }\end{array}$ & $0(0 \%)$ & $2(1.1 \%)$ & $2(1.1 \%)$ & \\
\hline \multirow[t]{4}{*}{$\begin{array}{l}\text { Equipment for } \\
\text { waste storage? }\end{array}$} & $\begin{array}{l}\text { Personal bin } \\
\text { collection }\end{array}$ & $43(22.95)$ & $\begin{array}{l}20 \\
(10.6 \%)\end{array}$ & $63(33.5 \%)$ & \multirow[t]{4}{*}{$9.317(0.025)$} \\
\hline & Garbage bags & $32(17.0 \%)$ & $\begin{array}{l}24 \\
(12.8 \%)\end{array}$ & $56(29.8 \%)$ & \\
\hline & Open dump & $21(11.2 \%)$ & $\begin{array}{l}26 \\
(13.8 \%)\end{array}$ & $47(25.0 \%)$ & \\
\hline & Thrown away & $17(9.0 \%)$ & $\begin{array}{l}5 \\
(2.7 \%)\end{array}$ & $22(11.7 \%)$ & \\
\hline \multirow[t]{4}{*}{$\begin{array}{l}\text { Waste disposal } \\
\text { methods }\end{array}$} & $\begin{array}{l}\text { Ibadan waste } \\
\text { management } \\
\text { sanitary dust bin }\end{array}$ & $24(12.8 \%)$ & $\begin{array}{l}18 \\
(9.6 \%)\end{array}$ & $42(22.5 \%)$ & $\begin{array}{l}24.015 \\
(0.000)\end{array}$ \\
\hline & $\begin{array}{l}\text { Ibadan waste } \\
\text { management } \\
\text { door-to-door } \\
\text { collection }\end{array}$ & $42(22.5 \%)$ & $\begin{array}{l}50 \\
(26.7 \%)\end{array}$ & $92(49.2 \%)$ & \\
\hline & Burning & $2(1.1 \%)$ & $0(0 \%)$ & $2(1.1 \%)$ & \\
\hline & Open dump & $44(23.5 \%)$ & $\begin{array}{l}7 \\
(3.7 \%)\end{array}$ & $51(27.3 \%)$ & \\
\hline \multirow[t]{4}{*}{$\begin{array}{l}\text { Method of liquid } \\
\text { waste disposal? }\end{array}$} & $\begin{array}{l}\text { Dung pit/Soak } \\
\text { away }\end{array}$ & $40(22.1 \%)$ & $\begin{array}{l}47 \\
(26.0 \%) \\
\end{array}$ & $87(48.1 \%)$ & \multirow[t]{4}{*}{$\begin{array}{l}21.068 \\
(0.000)\end{array}$} \\
\hline & Premises/Street & $23(12.7 \%)$ & $\begin{array}{l}3 \\
(1.7 \%) \\
\end{array}$ & $26(14.4 \%)$ & \\
\hline & Gutter/Road & $9(5.0 \%)$ & $\begin{array}{l}12 \\
(6.6 \%) \\
\end{array}$ & $21(11.6 \%)$ & \\
\hline & Anywhere & $9(5.0 \%)$ & $\begin{array}{l}12 \\
(6.6 \%) \\
\end{array}$ & $21(11.6 \%)$ & \\
\hline \multirow{4}{*}{$\begin{array}{l}\text { Frequency of waste } \\
\text { bin usage (per } \\
\text { week)? }\end{array}$} & 5 times & $20(10.6 \%)$ & $\begin{array}{l}20 \\
(10.6 \%)\end{array}$ & $40(21.3 \%)$ & \multirow[t]{4}{*}{$7.430(0.059)$} \\
\hline & 4 times & $14(7.4 \%)$ & $\begin{array}{l}17 \\
(9.0 \%) \\
\end{array}$ & $31(16.5 \%)$ & \\
\hline & 3 times & $51(27.1 \%)$ & $\begin{array}{l}26 \\
(13.8 \%) \\
\end{array}$ & $77(41.0 \%)$ & \\
\hline & Irregular & $28(14.9 \%)$ & $\begin{array}{l}12 \\
(6.4 \%) \\
\end{array}$ & $40(21.3 \%)$ & \\
\hline \multirow[t]{5}{*}{$\begin{array}{l}\text { Method of excreta } \\
\text { disposal? }\end{array}$} & Flushed toilet & $46(24.5 \%)$ & $\begin{array}{l}19 \\
(10.1 \%)\end{array}$ & $65(34.6 \%)$ & \multirow[t]{5}{*}{$\begin{array}{l}22.071 \\
(0.000)\end{array}$} \\
\hline & Latrine & $16(8.5 \%)$ & $\begin{array}{l}11 \\
(5.9 \%)\end{array}$ & $27(14.4 \%)$ & \\
\hline & Water closet & $35(18.6 \%)$ & $\begin{array}{l}41 \\
(21.8 \%)\end{array}$ & $76(40.4 \%)$ & \\
\hline & Nearby bush & $16(8.5 \%)$ & $\begin{array}{l}1 \\
(0.5 \%)\end{array}$ & $17(9.0 \%)$ & \\
\hline & $\begin{array}{l}\text { Nearby } \\
\text { Dumpsite }\end{array}$ & $0(0 \%)$ & $\begin{array}{l}3 \\
(1.6 \%) \\
\end{array}$ & $3(1.6 \%)$ & \\
\hline
\end{tabular}


DOI: 10.5281/zenodo.2653134

\begin{tabular}{|c|c|c|c|c|c|}
\hline \multirow{2}{*}{$\begin{array}{l}\text { Amount pay to } \\
\text { Ibadan waste } \\
\text { management per } \\
\text { month? }\end{array}$} & $<\$ 5,000$ & $106(59.6 \%)$ & $\begin{array}{l}69 \\
(38.8 \%)\end{array}$ & $175(98.3 \%)$ & \multirow[t]{2}{*}{$4.492(0.034)$} \\
\hline & $\begin{array}{l}\$ 5,001- \\
\$ 10,000\end{array}$ & $0(0 \%)$ & $\begin{array}{l}3 \\
(1.7 \%)\end{array}$ & $3(1.7 \%)$ & \\
\hline \multirow[t]{4}{*}{$\begin{array}{l}\text { Distance of dust } \\
\text { bins }\end{array}$} & Very far & $8(4.3 \%)$ & $\begin{array}{l}19 \\
(10.1 \%)\end{array}$ & $27(14.4 \%)$ & \multirow[t]{4}{*}{$\begin{array}{l}48.633 \\
(0.000)\end{array}$} \\
\hline & Far & $8(4.3 \%)$ & $\begin{array}{l}25 \\
(13.3 \%)\end{array}$ & $33(17.6 \%)$ & \\
\hline & Near & $97(51.6 \%)$ & $\begin{array}{l}28 \\
(14.9 \%)\end{array}$ & $125(66.5 \%)$ & \\
\hline & $\begin{array}{l}\text { None (No waste } \\
\text { bin) }\end{array}$ & $0(0 \%)$ & $\begin{array}{l}3 \\
(1.6 \%) \\
\end{array}$ & $3(1.6 \%)$ & \\
\hline \multirow[t]{5}{*}{$\begin{array}{l}\text { Waste bin } \\
\text { evacuation? }\end{array}$} & Most often & $27(14.5 \%)$ & $\begin{array}{l}18 \\
(9.7 \%)\end{array}$ & $45(24.2 \%)$ & \multirow[t]{5}{*}{$\begin{array}{l}20.934 \\
(0.000)\end{array}$} \\
\hline & More often & $1(0.5 \%)$ & $0(0 \%)$ & $1(0.5 \%)$ & \\
\hline & Very often & $23(12.4 \%)$ & $\begin{array}{l}22 \\
(11.8 \%)\end{array}$ & $45(24.2 \%)$ & \\
\hline & Often & $28(15.1 \%)$ & $\begin{array}{l}32 \\
(17.2 \%)\end{array}$ & $60(32.3 \%)$ & \\
\hline & Rare & $32(17.2 \%)$ & $\begin{array}{l}3 \\
(1.6 \%) \\
\end{array}$ & $35(18.8 \%)$ & \\
\hline \multirow{3}{*}{$\begin{array}{l}\text { Which of the } \\
\text { followings do you } \\
\text { think is the } \\
\text { environmental } \\
\text { impact of solid } \\
\text { waste in Ibadan } \\
\text { Metropolis? }\end{array}$} & Litter & $71(37.8 \%)$ & $\begin{array}{l}32 \\
(17.0 \%)\end{array}$ & $103(54.8 \%)$ & \multirow[t]{3}{*}{$\begin{array}{l}11.880 \\
(0.003)\end{array}$} \\
\hline & Odour/smoke & $38(20.2 \%)$ & $\begin{array}{l}43 \\
(22.9 \%)\end{array}$ & $81(43.1 \%)$ & \\
\hline & Eyesore & $4(2.1 \%)$ & $0(0 \%)$ & $4(2.1 \%)$ & \\
\hline
\end{tabular}

Source: Field Survey, 2018

From the above Table 2, in term of the types of waste categories that respondents dispose, $49.5 \%$ of the male dispose food waste, $12.8 \%$ dispose newspaper waste, $15 \%$ dispose magazine waste, $22.5 \%$ dispose carton boxes waste, $46.5 \%$ dispose refuse plastic sacks, $41.2 \%$ dispose plastic bottles, $22.5 \%$ dispose metal waste, $11.2 \%$ dispose glass waste, $31.6 \%$ dispose used clothes and fabrics waste, $33.7 \%$ dispose vegetable matter waste, $28.9 \%$ dispose grits waste, $21.4 \%$ dispose hedges and trees waste while $32.6 \%$ dispose rubber waste. Also, $34.6 \%$ of the female dispose food waste, $16 \%$ dispose newspaper waste, $10 \%$ dispose magazine waste, $13.4 \%$ dispose carton boxes waste, $29.4 \%$ dispose refuse plastic sacks, $30.5 \%$ dispose plastic bottles, $18.7 \%$ dispose metal waste, $12.3 \%$ dispose glass waste, $16.6 \%$ dispose used clothes and fabrics waste, $29.4 \%$ dispose vegetable matter waste, $24.6 \%$ dispose grits waste, $25.1 \%$ dispose hedges and trees waste while $29.4 \%$ dispose rubber waste.

Based on the number of plot of land that the accommodation of the respondents are built on, 30.3\% of the male respondents have their accommodation build on a plot of land, $15.4 \%$ have their accommodation build on two plots of land, 5.3\% have their accommodation build on three plots of land while $9 \%$ of the male have their accommodation build on other number of plots of land, 
considering the female respondents, $27.1 \%$ of the female respondents in this research work have their accommodation build on a plot of land, $6.9 \%$ have their accommodation build on two plots of land, $0.5 \%$ have their accommodation build on three plots of land while $5.3 \%$ of the female have their accommodation build on other number of plots of land. Concerning duration of waste generation (Days) by respondents, $43.1 \%$ of the male respondents generate waste of about $1-2 \mathrm{~kg}$ per day, $14.4 \%$ generate waste of $3-4 \mathrm{~kg}$ per day, $2.7 \%$ generate waste of $5-6 \mathrm{~kg}$ per day, on the other hand $23.4 \%$ of the female generate waste of about $1-2 \mathrm{~kg}$ per day, $12.8 \%$ generate waste of about $3-4 \mathrm{~kg}$ per day, $2.7 \%$ generate waste of $5-6 \mathrm{~kg}$ per day while $1.1 \%$ of the female generate waste of $7 \mathrm{~kg}$ per day and above. In relation to the equipment of waste storage use by the respondents, $22.95 \%$ of the male use personal bin collection for storing waste, $17 \%$ use garbage bags, $11.2 \%$ use open dump while $9 \%$ throw their waste away, considering the female respondents $10.6 \%$ of the female respondents use personal bin collection for storing waste, $12.8 \%$ use garbage bags, $13.8 \%$ use open dump while $2.7 \%$ throw their waste away.

Regarding the methods of waste disposal by respondents, $12.8 \%$ of the male dispose their waste to the Ibadan waste management sanitary dust bin, $22.5 \%$ dispose their waste to the Ibadan waste management door-to-door collection, $1.1 \%$ dispose their waste by burning them while $23.5 \%$ dispose theirs to the open dump. Also, $9.6 \%$ of the female dispose their waste to the to the Ibadan waste management sanitary dust bin, $26.7 \%$ dispose their waste to the Ibadan waste management door-to-door collection while $3.7 \%$ dispose theirs to the open dump. In respect to the method of liquid waste disposal by respondents, $22.1 \%$ of the male dispose their liquid waste into dung pit/soak away, $12.7 \%$ dispose their liquid waste to the premises street, $5 \%$ dispose theirs into gutter/road while 5\% dispose theirs anywhere they like. On the hand, $26 \%$ of the female dispose their liquid waste into dung pit/soak away, $1.7 \%$ dispose their liquid waste to the premises street, $6.6 \%$ dispose theirs into gutter/road while $6.6 \%$ dispose theirs anywhere they like. In terms of the frequency of waste bin usage (per week), $10.6 \%$ of the male use their waste bin 5 times per week, $7.4 \%$ use their waste bin 4 times per week, $27.1 \%$ use theirs 3 times per week while $14.9 \%$ use their waste bin irregularly. Also, $10.6 \%$ of the female use their waste bin 5 times per week, $9 \%$ use their waste bin 4 times per week, $13.8 \%$ use theirs 3 times per week while $6.4 \%$ use their waste bin irregularly.

Concerning the methods of excreta disposal, $24.5 \%$ of the male use flushed toilet for their excreta disposal, $8.5 \%$ use latrine for their excreta disposal, $18.6 \%$ use water closet while $8.5 \%$ dispose their excreta to nearby bush, considering the female respondents, $10.1 \%$ of the female respondents use flushed toilet for their excreta disposal, 5.9\% use latrine for their excreta disposal, $21.8 \%$ use water closet, $0.5 \%$ dispose their excreta to nearby bush while $1.6 \%$ of the female respondents dispose their excreta to nearby dumpsite. Regarding the amount pay by respondents to the Ibadan waste management per month, it was seen that most of the male respondents $(59.6 \%)$ pay less than $\$ 5,000$ to the Ibadan waste management per month, in respect of the female respondents, it was seen that $38.8 \%$ pay less than $\$ 5,000$ to the Ibadan waste management per month while $1.7 \%$ pay between the range of $\$ 5,001-\$ 10,000$ to the Ibadan waste management per month. In view of the distance of dust bins to their residence, it was seen that $4.3 \%$ of the male have their dust bins very far away from them, $4.3 \%$ have their dust bins far away from them, 51.6\% have their dust bins near to them, In terms of the female respondents, $10.1 \%$ of the female have their dust bins very far away from them, $13.3 \%$ have their dust bins far away from them, $14.9 \%$ have their dust bins near to them while $1.6 \%$ of the female have no waste bin. 
Regarding to the frequency of waste bin evacuation, $14.5 \%$ of the male most often evacuate their waste bin, $0.5 \%$ more often evacuate their waste bin, $12.4 \%$ very often evacuate their waste bin, $15.1 \%$ often evacuate their waste bin while $17.2 \%$ rarely evacuate their waste bin. Also, $9.7 \%$ of the female most often evacuate their waste bin, $11.8 \%$ very often evacuate their waste bin, $17.2 \%$ often evacuate their waste bin while $1.6 \%$ rarely evacuate their waste bin. Considering the respondents' view on the environmental impact of solid waste in Ibadan metropolis, $37.8 \%$ of the male believe that litter was the environmental impact of solid waste in Ibadan metropolis, 20.2\% see odour/smoke as the environmental impact of solid waste in Ibadan metropolis while $2.1 \%$ agree that eyesore is the environmental impact of solid waste in Ibadan metropolis, on the other hand, $17 \%$ of the female believe that litter was the environmental impact of solid waste in Ibadan metropolis while $20.2 \%$ of them see odour/smoke as the environmental impact of solid waste in Ibadan metropolis.

Table 3: Economic Analysis of Solid Waste from the Contractors Side

\begin{tabular}{|c|c|c|}
\hline Questions & Category & Percentage \\
\hline \multirow[t]{4}{*}{ Years of operation? } & 1 & 3.2 \\
\hline & 1.6 & 3.2 \\
\hline & 2 & 9.6 \\
\hline & 4 & 6.9 \\
\hline \multirow[t]{5}{*}{ Number of vehicles used? } & 1 & 3.2 \\
\hline & 2 & 3.2 \\
\hline & 3 & 3.2 \\
\hline & 4 & 3.2 \\
\hline & 5 & 10.1 \\
\hline \multirow[t]{6}{*}{ Number of houses covered per month? } & 100 & 3.2 \\
\hline & 120 & 3.2 \\
\hline & 150 & 3.2 \\
\hline & 200 & 3.2 \\
\hline & 250 & 3.2 \\
\hline & 300 & 6.9 \\
\hline \multirow[t]{6}{*}{ Number of solid waste container managed? } & 20 & 3.2 \\
\hline & 25 & 3.2 \\
\hline & 30 & 3.2 \\
\hline & 40 & 3.2 \\
\hline & 50 & 3.2 \\
\hline & 70 & 6.9 \\
\hline \multirow[t]{5}{*}{ Monthly fee charged for service provision? } & $¥ 1,500$ & 3.2 \\
\hline & $\$ 2,000$ & 6.4 \\
\hline & $¥ 2,500$ & 3.2 \\
\hline & $\$ 3,000$ & 6.9 \\
\hline & $\$ 5,000$ & 3.2 \\
\hline \multirow{4}{*}{$\begin{array}{l}\text { Average number of times truck is serviced per } \\
\text { month? }\end{array}$} & 2 & 3.2 \\
\hline & 3 & 3.2 \\
\hline & 4 & 6.4 \\
\hline & 5 & 10.1 \\
\hline
\end{tabular}




\begin{tabular}{|c|c|c|}
\hline \multirow[t]{5}{*}{ Number of trip made to dump site per month? } & 2 & 3.2 \\
\hline & 5 & 3.2 \\
\hline & 8 & 3.2 \\
\hline & 10 & 10.1 \\
\hline & 12 & 3.2 \\
\hline \multirow{2}{*}{$\begin{array}{l}\text { Types of operation performed by the waste } \\
\text { contractors? }\end{array}$} & Collection and disposal & 16.5 \\
\hline & $\begin{array}{l}\text { Collection, Disposal, Sorting and } \\
\text { Recycling }\end{array}$ & 6.4 \\
\hline \multirow{5}{*}{$\begin{array}{l}\text { Quantity purchased of re-usable waste } \\
\text { material (kg) from you? }\end{array}$} & 10 & 3.2 \\
\hline & 20 & 3.2 \\
\hline & 25 & 6.4 \\
\hline & 30 & 6.9 \\
\hline & 40 & 3.2 \\
\hline \multirow[t]{2}{*}{ Buying price of re-usable waste material $(\mathrm{kg}) ?$} & $¥ 250$ & 12.8 \\
\hline & $\$ 300$ & 10.1 \\
\hline \multirow{5}{*}{$\begin{array}{l}\text { Quantity purchased of recycled waste material } \\
(\mathrm{kg}) \text { from you? }\end{array}$} & 10 & 3.2 \\
\hline & 15 & 10.1 \\
\hline & 20 & 3.2 \\
\hline & 25 & 3.2 \\
\hline & 30 & 3.2 \\
\hline \multirow[t]{2}{*}{ Buying price of recycled waste material $(\mathrm{kg}) ?$} & $¥ 250$ & 10.1 \\
\hline & $\$ 300$ & 12.8 \\
\hline
\end{tabular}

Source: Field Survey, 2018

From Table 3 above, it was observed that $3.2 \%$ of the contractors has been operating for the past one year, 3.2\% of them have been operating for the past one year and six month and $9.6 \%$ of the contractors has been operating for the past two years while the remaining $6.9 \%$ of the contractors has been operating for the past four years. In the same vein, $3.2 \%$ of the contractors has only one vehicle for their operation, $3.2 \%$ of the contractors has two vehicles for their operation, $3.2 \%$ of the contractors has three vehicles for their operation and $3.2 \%$ of the contractors has four vehicles for their operation while the remaining $10.1 \%$ of the contractors has five vehicles for their operation. Also, 3.2\% of the contractors cover 100 houses per month, $3.2 \%$ of the contractors cover 120 houses, $3.2 \%$ of the contractors cover 150 houses, $3.2 \%$ of the contractors cover 200 houses and $3.2 \%$ of the contractors cover 250 houses while the remaining $6.9 \%$ of the contractors cover 300 houses.

Furthermore, $3.2 \%$ of contractors managed 20 containers per month, $3.2 \%$ of contractors managed 25 containers per month, 3.2\% of contractors managed 30 containers per month, $3.2 \%$ of contractors managed 40 containers per month and $3.2 \%$ of contractors managed 50 contractors while $6.9 \%$ of contractors managed 70 container per month. Therefore, $3.2 \%$ of contractors charge $\$ 1,500$ per month, $6.4 \%$ of contractors charge $\$ 2,000$ per month, $3.2 \%$ of contractors charge $\$ 2,500$ per month and $6.9 \%$ of contractors charge $\$ 3,000$ per month while $3.2 \%$ of contractors charge $\$ 5,000$ per month. Also, $3.2 \%$ of contractors serviced their truck two times per month and some three per month and $6.4 \%$ of contractors serviced their truck four times per month while $10.1 \%$ of contractors serviced their truck five times per month. Furthermore, $3.2 \%$ of contractors made two, five and eight trips to dump site per month and $10.1 \%$ of contractors made ten trips to 
dump site per month while $3.2 \%$ of contractor made twelve trips to dump site per month. Also, $16.5 \%$ of contractors operation covers collection and disposal while $6.4 \%$ of contractors operation covers collection, disposal, sorting and recycling.

In the same manner, $3.2 \%$ of contractors said that the quantity of re-useable waste material purchased from them was 10 to $20 \mathrm{~kg}, 6.4 \%$ of contractors said that the quantity of re-useable waste material purchased from them was $25 \mathrm{~kg}$ and $6.9 \%$ of contractors said that the quantity of re-useable waste material purchased from them was $30 \mathrm{~kg}$ while the remaining $3.2 \%$ said that the quantity of re-useable waste material purchased from them was $40 \mathrm{~kg}$. Based on price that contractors charged on re-useable, it was revealed that the price charges on re-useable was $\$ 250$ and $\$ 300$ per $\mathrm{kg}$. Also, 3.2\% said that the quantity of recycled waste material purchased from them was $10 \mathrm{~kg}, 20 \mathrm{~kg}, 25 \mathrm{~kg}$ and $30 \mathrm{~kg}$ while the remaining $10.1 \%$ said that the quantity of recycled waste material purchased from them was $15 \mathrm{~kg}$ and the price charges on recycled was $\$ 250$ and $\$ 300$ per $\mathrm{kg}$.

Table 4: Factors Militating against the Level of Efficiency of Waste Management Board in Ibadan in Terms of Waste Disposal

\begin{tabular}{|l|l|l|}
\hline & Yes & No \\
\hline Insufficient fund & $72.3 \%$ & $27.7 \%$ \\
\hline Inadequate trained personnel & $69.1 \%$ & $30.9 \%$ \\
\hline No financial sacrifices for environment protection & $68.6 \%$ & $29.8 \%$ \\
\hline Lack of proper education by the people & $70.7 \%$ & $29.3 \%$ \\
\hline Poor equipment & $80.9 \%$ & $19.1 \%$ \\
\hline Negligence of duty & $68.6 \%$ & $31.4 \%$ \\
\hline Increasing population & $72.9 \%$ & $27.1 \%$ \\
\hline Lack of adequate awareness on the part of the public on management of wastes & $78.7 \%$ & $21.3 \%$ \\
\hline Lack of air pollution and control devices by industries & $77.7 \%$ & $22.3 \%$ \\
\hline Poor enforcement of the waste management regulation & $86.2 \%$ & $13.8 \%$ \\
\hline Culture of the people seems not to respect human dignity and decency & $80.3 \%$ & $19.7 \%$ \\
\hline Increased industrialization and consumption of fresh raw materials & $61.2 \%$ & $38.8 \%$ \\
\hline
\end{tabular}

Source: Field Survey, 2018

The above Table 4, 72.3\% of the respondents reveals that insufficient fund was the factor militating against the level of efficiency of waste management board in Ibadan in terms of waste disposal while the remaining $27.7 \%$ didn't agreed to this. Also, $69.1 \%$ said that inadequate trained personnel was the factor militating against the level of efficiency of waste management board in Ibadan in terms of waste disposal while $30.9 \%$ said that it is not. Furthermore, $68.6 \%$ of the respondents said that no financial sacrifices for environment protection was the factor militating against the level of efficiency of waste management board in Ibadan in terms of waste disposal and the remaining $29.9 \%$ said it was not so. Also, $70.7 \%$ of the respondents said that lack of proper education by the people was the greatest factor militating against the level of efficiency of waste management board in Ibadan in terms of waste disposal and $29.3 \%$ said that it has nothing to do with the factor militating against the level of efficiency of waste management board in Ibadan in terms of waste disposal. In the same manner, $80.9 \%$ of the respondents said that poor equipment is the course of inefficiency of waste management board in Ibadan in terms of waste disposal and $19.1 \%$ said that it is not. 
Furthermore, $68.6 \%$ of the respondents said that negligence of duty is the factor militating against the level of efficiency of waste management board in Ibadan in terms of waste disposal while $31.4 \%$ said that it is not. Also, $72.9 \%$ said that increasing population was the factor militating against the level of efficiency of waste management board in Ibadan in terms of waste disposal while $27.1 \%$ said that population increase does not affect the level of efficiency of waste management board in Ibadan in terms of waste disposal. In the same vein, 78.7\% said that lack of adequate awareness on the part of the public on management of wastes was the factor militating against the level of efficiency of waste management board in Ibadan in terms of waste disposal while $21.3 \%$ said it is not. Also, $77.7 \%$ said lack of air pollution and control devices by industries was the factor militating against the level of efficiency of waste management board in Ibadan in terms of waste disposal and the remaining $22.3 \%$ said that it is not. Also, $86.2 \%$ of the respondents said that poor enforcement of the waste management regulation was the factor militating against the level of efficiency of waste management board in Ibadan in terms of waste disposal while the remaining $13.8 \%$ said that it is not. Also, $80.3 \%$ of the respondents said that culture of the people seems not to respect human dignity and decency was the factor militating against the level of efficiency of waste management board in Ibadan in terms of waste disposal while $19.7 \%$ said that it is not. Lastly, $61.2 \%$ of the respondents said that increased industrialization and consumption of fresh raw materials was the factor militating against the level of efficiency of waste management board in Ibadan in terms of waste disposal and the remaining $38.8 \%$ said that it is not.

Table 5: Ordinary Least Square (OLS) Regression Analysis of Economic Analysis of Solid Waste Management in Ibadan Metropolis

\begin{tabular}{|l|c|c|c|}
\hline Dependent Variable & Amount Pay to Ibadan Waste Management per Month \\
\hline Independent Variable & \multicolumn{2}{|c|}{ t-stat } \\
\hline Income of the Household & \multicolumn{2}{|c|}{$-1.85^{* * *}$} & -0.37 \\
\hline Household Size & -0.005 & $-1.92^{* * *}$ & \\
\hline Educational Status & -0.023 & 1.36 & \\
\hline Housing Type & 0.009 & 0.11 & \\
\hline Extra Land Area & 0.001 & -1.47 & \\
\hline Quantity of Waste per Household & -0.024 & $-4.60^{*}$ & \\
\hline Age & -0.008 & $3.26^{*}$ & \\
\hline Sex & 0.068 & $3.12^{*}$ & \\
\hline Cons_ & 0.394 & & \\
\hline F(8, 169$)$ & $5.43\left(0.000^{*}\right)$ & & \\
\hline R-Squared & 0.2044 & & \\
\hline Adj. R-Squared & 0.1668 & & \\
\hline Root MSE & 0.1178 & & \\
\hline
\end{tabular}

Source: Field Survey, 2018

Note that $* * * \& * * *$ represent $1 \%, 5 \%$ \& $10 \%$ level of significant

The coefficient of determination $\left(\mathrm{R}^{2}\right)$ is 0.2044 which shows that $20.44 \%$ of the variation in the amount pay to Ibadan waste management per month was explained by the independent variables while adjusted coefficient of determination (adjusted $\mathrm{R}^{2}$ ) shows the exact variation which is only $16.68 \%$ of the total variation in the amount pay to Ibadan waste management per month was explained by the independent variables. Also, the F-statistics of 5.43 with a p-value of 0.000 indicates that the overall model is statistically significant at $1 \%$ level of significant. The result 
shows that four variables (income of the household, educational status, age and sex) were all significant at $1 \%$ and $10 \%$ level of significant while household size, housing type, extra land area and quantity of waste per household were not significant.

Table 6: Logistics Regression Analysis on Willingness-to-Pay for Environmental Goods in Ibadan Metropolis

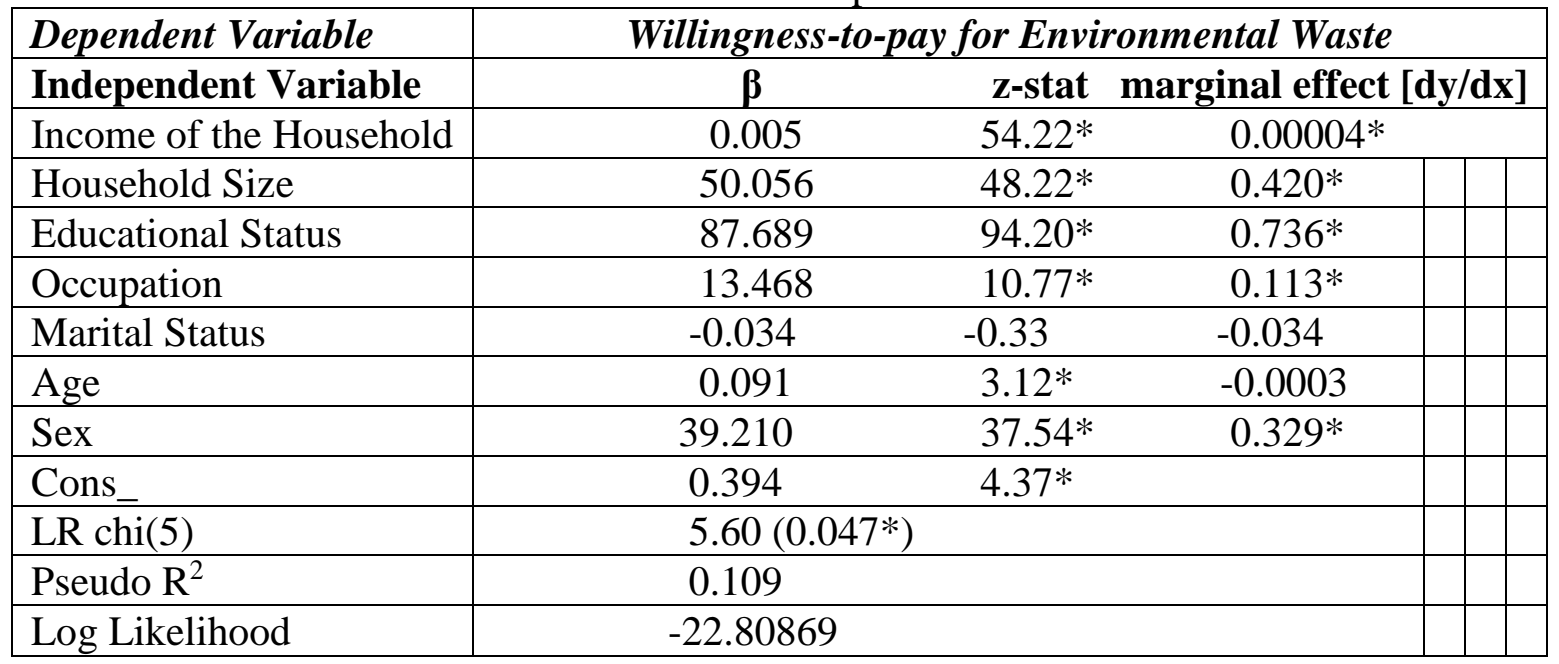

Source: Field Survey, 2018

Note that $* * * \& * * *$ represent $1 \%, 5 \%$ \& $10 \%$ level of significant

Table 6 summaries the logistic regression result on willingness-to-pay for environment goods. The Log likelihood was -22.81 . The Log likelihood ratio test as measured by the chi-square was 5.60 with a p-value of 0.047 . That means even at 1 percent, the null hypothesis that the model was not a good fit was rejected in favour of the alternative hypothesis that the model was a good fit. The choice to have a willingness to pay or not (WTP), was found to be inelastic to changes in income of the household. The elasticity between income of the household and WTP for environmental goods in Ibadan metropolis was inelastic at 0.00004. An increase in income of the household by one unit however had the possibility of increasing the WTP as evidenced by the positive sign. Household size was also inelastic in influencing the WTP environmental goods in Ibadan metropolis. The educational status elasticity of WTP was 0.36 ; therefore, educational status influences the level of WTP in the area. However, there was a positive elasticity meaning that those who were educated were more likely to have a positive WTP for environmental goods in Ibadan metropolis. The elasticity of WTP due to occupation was estimated at 0.113 which is inelastic. Therefore, as occupation increase by one unit, WTP for environmental waste will increase. Lastly, sex of the respondents also was inelastic in influencing the WTP for environmental goods in Ibadan metropolis. This means that although the relationship was inelastic, gender has a positive WTP for environmental goods in Ibadan metropolis.

Table 7: Gross Margin (GM) and Net Income Analysis

\begin{tabular}{|l|l|l|}
\hline Items & $\begin{array}{l}\text { Amount (\#) per } \\
\text { Month }\end{array}$ & $\begin{array}{l}\text { Percentage of Total } \\
\text { Revenue }\end{array}$ \\
\hline Revenue & & \\
\hline $\begin{array}{l}\text { No of solid waste managed multiply by } \\
\text { monthly fee charges }\end{array}$ & $120,225.7$ & \\
\hline
\end{tabular}




\begin{tabular}{|l|l|l|}
\hline $\begin{array}{l}\text { Quantity purchased of re-used multiply by } \\
\text { price of re-used }(\mathrm{kg})\end{array}$ & $7,023.731$ & \\
\hline $\begin{array}{l}\text { Quantity purchased of recycled multiply by } \\
\text { price of recycled }(\mathrm{kg})\end{array}$ & $5,138.111$ & \\
\hline Total Revenue & $\mathbf{1 3 2 , 3 8 7 . 5}$ & \\
\hline Variables Cost & & 4.99 \\
\hline Fuel & $6,604.7$ & 9.64 \\
\hline Labour & 12,767 & 8.22 \\
\hline Track (Vehicle) hiring & 10,884 & 1.30 \\
\hline Electricity bill & $1,723.3$ & \\
\hline Total Variables Cost & $\mathbf{3 1 , 9 7 9}$ & \\
\hline Gross Margin & $\mathbf{1 0 0 , 4 0 8 . 5 2 9 9}$ & \\
\hline Fixed Cost & & 2.72 \\
\hline Dump site charges & $3,604.7$ & 0.41 \\
\hline Hand gloves & 541.86 & 0.57 \\
\hline Levies & 748.84 & 3.14 \\
\hline Rents & $4,162.8$ & 2.96 \\
\hline Shovel & 3918.6 & 0.44 \\
\hline Tax & 579.53 & \\
\hline Total Fixed Cost & $\mathbf{1 3 , 5 5 6 . 3 3}$ & \\
\hline Net Income & $\mathbf{8 6 , 8 5 2 . 2 0}$ & \\
\hline Source: Fid Survey, & & \\
\hline
\end{tabular}

Source: Field Survey, 2018

Table 7 shows the gross margin and net income analysis of the contractors in Ibadan metropolis. The average monthly variable and fixed cost of waste management business are $\$ 31,979$ and $\$ 13,556.33$ respectively. This shows that $70.23 \%$ of the monthly total cost of operating the business is incurred on the variable inputs. In the same vein, the result reveals that gross margin and net income from waste management business are $\$ 100,408.5299$ and $\$ 86,852.20$ per month. This high gross margin and net income can be attributed to the fact that waste contractors own their vehicle for their waste disposals. Therefore, it is worth why concluding that the business of waste management to the contractors in the study area are lucrative.

\section{Summary and Conclusion}

The study investigated the economic analysis of solid waste management of Ibadan metropolis, Oyo State: Evidences from value belief norm (VBN) and willingness-to-pay theory. The study distributed two hundred and fifty (250) to both household and contractors and two hundred questionnaires was distributed to household while fifty questionnaires for contractors. The methods used include descriptive statistic, cross tabulation, both ordinary least square (OLS) and logistic regression as well as gross margin and net income analysis. The OLS regression result revealed that income of the household, educational status, age and sex are the factors that determine the amount pay to Ibadan waste management per month in Ibadan metropolis while the factors that determine willingness-to-pay for environmental goods in Ibadan metropolis from logistic regression are income of the household, household size, educational status, occupation and sex and they are inelastic in nature. Furthermore, gross margin and net income from waste management business to the contractors sampled are $\$ 100,408.5299$ and $\$ 86,852.20$ per month 
respective. The study recommended that contractors in the study area can jointly establish recycle plants where they can recycle waste and make more income from the recycled products. Waste management contractors in the study area should be prompt in their service delivery. Also, every household should have solid waste facilities such as garbage bin and dustbin for easy disposal. Lastly, government should re-introduced the monthly sanitation in order to make a lot of household become more conscious of the purity of their surroundings.

\section{References}

[1] Abdullahi, M.; Ajibike, A.; Man-Ugwueje, P. and Ndububa, O. I.; (2014). Environmental Impact of Indiscriminate Waste Disposal, A Case Study of Nigerian Airforce Base Kaduna. International Journal of Engineering and Applied Sciences (IJEAS), 1(1)

[2] Abur, B. T.; Oguche, E. E. and Duvuna, G. A.; (2014). Characterization of Municipal Solid Waste in the Federal Capital Abuja, Nigeria. Global Journal of Science Frontier Research: H Environment \& Earth Science, 14(2): $1-7$.

[3] Adebo, G. M. and Ajewole, O. C.; (2012). Gender and the Urban Environment: Analysis of Willingness to pay for Waste Management Disposal in Ekiti-State, Nigeria. American International Journal of Contemporary Research, 2(5): 228 - 236.

[4] Adeoti, A. and Obidi, B.; (2013). Poverty and Preference for Improved Solid Waste Management Attributes in Delta-State, Nigeria. Journal of Rural Economics and Development, 19(1): 15 - 33.

[5] Adesiyan, B.; (2000). Solid Waste Management in the Core Area of Ibadan. Paper presented in a conference of Directors and General Managers in charge of Environmental Matters in Ibadan.

[6] Agbaeze, E. K.; Onwuka, I. O. and Agbo, C. C.; (2014). Impact of Sustainable Solid Waste Management on Economic Development - Lessons from Enugu State Nigeria. Journal of Economics and Sustainable Development, 5(9): 130 - 139.

[7] Ajani, O. I. Y.; (2008). Determinants of an Effective Solid Waste Management in Ibadan Metropolis, Oyo State, Nigeria. Journal of Food, Agriculture \& Environment, 6(1): 152 - 157.

[8] Aliu, I. R.; Adeyemi, O. E. and Adebayo, a.; (2014). Municipal Household Solid Waste Collection Strategies in an African Megacity: Analysis of Public Private Partnership Performance in Lagos. Waste Management \& Research, 32(9): 67 - 78.

[9] Anthony, K. O.; (2011). Impact of Municipal Solid Wastes on Underground Water Sources in Nigeria. European Scientific Journal, 8(11): 1 - 19.

[10] Awosusi, A. O.; (2010). Assessment of Environmental Problems and Methods of Waste Management in Ado-Ekiti, Nigeria, 4(3B): 331 - 343.

[11] Ayanshola, A. M.; Aremu, A. S.; Jacob, S. O.; Bilewu, S. O. and Salami, A. W.; (2015). Evaluation of Municipal Solid Waste Management System and Willingness-to-Pay for its Improvements in Ilorin, Kwara State, Nigeria. Nigerian Journal of Technology (NIJOTECH), 34(4): 868 - 874.

[12] Becker, M. and Maiman, T.; (1975). The Health Belief Model and Personal Health Behaviour. Health Education Monograph; 12.

[13] CPE (Centre for People and Environment), 2010. Landfill Recovery and Use in Nigeria (PreFeasibility Studies of Using Lfge. Retrieved from: www.globalmethane.org.

[14] Eleje, E. O.; Anienwelu, P. C. and Adebayo, G. A.; (2017). Financial and Economic Implications of Solid Waste Management in Nigeria. JORIND, 15(1): 330 - 340.

[15] Gillani, S. Y. M.; Khan, R. E. A. and Gill, A. R.; (2015). Unemployment and Property Crimes in Pakistan. Asian Economic and Financial Review, 1(3): 124 - 133.

[16] Hanemann, W. M.; (1994). Valuing the Environment through Contingent Valuation. The Journal of Economic Perspectives, 8(4): $19-43$.

[17] Ibiyemi, A. O.; (2008). Economics of Solid Waste Management in Lagos State. Yaba Journal of Environmental Research, Yaba College of Technology, 1(1): 76-84. 
[18] Igwe, K. C. and Mgbasonwu, V. N.; (2017). Economic Analysis of Household Waste Generation, Disposal and Management in Umuahia Metropolis, Abia State, Nigeria. International Journal of Health Economics and Policy, 2(2): 47 - 56.

[19] Lohri, C. R.; Camenzind, E. J. and Zurbrugg, C.; (2014). Financial Sustainability in Municipal Solid Waste Management - Costs and Revenues in Bahir Dar, Ethiopia. Waste Management, 34: $542-552$.

[20] Maloma, I. and Sekatane, M. B.; (2014). Factors that Determine the Stated Willingness to Pay for Air Pollution: A Case of Bophelong Township. International Journal of Social Sciences and Humanity Studies, 6(2): $1-11$.

[21] Miyata, Y.; Shibusawa, H. and Hossain, N.; (2016). An Economic Analysis of Municipal Solid Waste Management of Toyohashi City, Japan: Evidences from Environmental Kuznets Curve, 1 12.

[22] Momodu, N. S.; Dimuna, K. O. and Dimuna, J. E.; (2011). Mitigating the Impact of Solid Wastes in Urban Centres in Nigeria. J Hum Ecol, 34(2): 125-133.

[23] Nas, T. F.; (1996). Cost-Benefit Analysis: Theory and Application, London: Sage Publications.

[24] Onwughara, I. N.; Nnorom, I. C. and Kanno, O. C.; (2010). Issues of Roadside Disposal Habit of Municipal Solid Waste, Environmental Impacts and Implementation of Sound Management Practices in Developing Country "Nigeria"., 1(5): 409 - 418.

[25] Pearce, D.; Marglin, S. and Sen, A. K.; (1993). Guidelines for Project Evaluation. United National Industrial Development Organization, New York. 383.

[26] Pervez, A. and Kafeel, A.; (2013). Impact of Solid Waste on Health and the Environment. Special Issue of International Journal of Sustainable Development and Green Economics (IJSDGE), 2(1): $1-2$.

[27] Stern, P. C.; (2000). Toward a Coherent Theory of Environmentally Significant Behavior. Journal of Social Issues, 56(3): $407-424$.

[28] Tan, S. T.; Ho, W. S.; Hashim, H.; Lee, C. T.; Taib, M. R. and Ho, C. S.; (2015). Energy, Economic and Environmental (3E) Analysis of Waste-to-Energy (WTE) Strategies for Municipal Solid Waste (MSW) Management in Malaysia. Energy Conversion and Management, xxx: xxx-xxx

[29] Todaro, M.P, and Smith, S.G, (2006), Economic development, New York: Pearson.

[30] Ugwu, E. C. and Ahaneku, I. E.; (2015). Economic Analysis of Solid Waste Disposal Scenarios in Nigeria using BATNEEC Model. Umudike Journal of Engineering and Technology (UJET), 1(1): $25-33$.

[31] United Nations Environment Program Agency (UNEPA, 2014). Informal Solid Waste Management. http://www.unep.org?PDF/Kenyawastemngntsector/chapter1.pdf

[32] Yusuf, S. A. and Adesola, A. B.; (2015). Benefit Incidence Analysis of Government Expenditure on Solid Waste Management in Osun State, Nigeria. Journal of Economics and Rural Development, 16(1): $59-70$.

*Corresponding author.

E-mail address: E011962.oyelade@ dlc.ui.edu.ng/adontopdominating@ gmail.com 